\title{
EFEKTIVITAS SERBUK DAUN TANAMAN KAYU MANIS (Cinnamomum burmanii) TERHADAP DIFERENSIAL LEUKOSIT DAN AKTIVITAS FAGOSITOSIS IKAN NILA (Oreochoromis niloticus) YANG DIINFEKSI Streptococcus agalactiae
}

\author{
Sri Wulandari ${ }^{1}$, Rahmad Jumadi ${ }^{2}$, Firma Fika Rahmawati ${ }^{2}$ \\ ${ }^{1}$ Mahasiswa Prodi Budi Daya Perikanan Fakultas Pertanian Universitas Muhammadiyah Gresik \\ ${ }^{2}$ Dosen Prodi Budi Daya Perikanan Fakultas Pertanian Universitas Muhammadyah Gresik \\ Email : eka.wulandari1503@gmail.com, Phone +6285655089517
}

\begin{abstract}
The main problem in the cultivation of tilapia is the attack of bacterial disease Streptococcosis caused by Streptococcus agalactiae bacteria. Alternative measures to prevent the disease of Streptocococis can be through the use of phytopharmaca materials. One of the ingredients of phytopharmaca can be used is cinnamon plant. Cinnamon leaves contain several types of active substances such as tannins, eugenol, safrole, calcium oxalate, resin, saponins, tanners, and sinamaldehid. The objective of the study of effectiveness of leaf powder of cinnamon plant to leukocyte differential and phagocytic activity in tilapia (Oreochromis niloticus) infected by Streptococcus agalactiae is to know the influence and dosage of cinnamon leaf powder in feed toLeukocyte Differentiation and Phagocytosis Activity Postcainfection Streptococcus agalactiae in tilapia (Oreochromis niloticus). This research used 3treatment 4 replication and control with dose $\mathrm{K}-=$ challenge test, $\mathrm{K}+=$ without test challenge, $\mathrm{A}=$ dose $0,25 \%, \mathrm{~B}=$ dose $0,5 \%, \mathrm{C}=1 \%$. The parameters observed are Leukocyte Differential and Phagocytosis Activity. Dosage 0.5\% addition of leaf powder cinnamon plant on feed is the best dose. Giving of cinnamon leaf powder in feed influenced to increase of leukocyte difference especially on monocyte cell and neutrophil cell was significantly different $(\mathrm{P}>0,05)$ than $\mathrm{K}+$ without addition of cinnamon leaf powder while phagocytic activity had an effect on Streptococcus agacatiae.
\end{abstract}

Keywords: Tilapia, Differential Leucocytes, Phagocytosis Activity, cinnamon leaf powder.

\section{PENDAHULUAN \\ Latar Belakang}

Ikan nila merupakan jenis ikan yangmempunyai nilaiekomomistinggidanmerupakan komoditas penting dalam bisnisikan air tawar dunia. Beberapa halyang mendukung pentingnya budidaya nila yaituresitensi terhadap penyakit toleransiterhadap salinitas sehingga tumbuh padaperairan payau dengan salinitas $0-25$ ppt. Produksi nila di Indonesia meningkat secarasignifikan dari tahun ke tahun yakni 21,41\%.Pada tahun 2010 produksi ikan nila 469.173ton, pada tahun 2011 meningkatmenjadi639.300 ton, dan pada tahun 2012 mencapai850.000 ton (KKP, 2013). Pada kegiatan budidaya ikan nila banyak terdapat permasalahan salah satunya serangan wabah penyakit. Serangan wabah penyakit terjadi sebagai akibat gangguan keseimbangan dan interaksi antara ikan, lingkungan yang tidak menguntungkan ikan dan berkembangnya patogen penyebab penyakit. Serangan wabah penyakit yang banyak menyerang ikan air tawar, khususnya ikan nila adalah penyakit bakterial yaitu Streptococcosis yang disebabkan oleh bakteri Streptococcusagalactiae. Wabah bakteri Streptococcus agalactiaee bersifat akut dan dapatmenyebabkan kematian tinggi hingga mencapai 100\% pada ikan budidaya (Hernandez et al. 2009). 
Pencegahan penyakit dalam budidaya ikan terutama penyakit bakterial yaitu Streptococcosis, khususnya pada komoditas ikan nila masih menggunakan bahan-bahan kimia seperti antibiotik, obat-obatan antimikroba dan desinfektan. Penggunaan obat-obatan memberikan dampak negatif dengan meningkatnya pencemaran lingkungan (Rairakhwada2007), akumulasi residu antibiotik mempengaruhi pertumbuhan dan resistensi terhadap obat-obatan serta imunosupresi (Maqsood et al., 2009). Dampak negatif tersebut dapat dicegah dengan cara meningkatkan kekebalan tubuh ikan terhadap penyakit (Selvaraj et al., 2006).

Upaya alternatif guna pencegahan penyakit Streptocococis dapat melalui penggunaan bahan fitoformaka. Salah satu bahan fitofarmaka dapat digunakan adalahtumbuhan kayu manis. Manfaat mengonsumsi kayu manis antara lain dapat menurunkan kolesterol, menurunkan kadar gula darah, anti jamur, anti virus, anti parasit, antiseptik dan sebagai antibakteri. Daun kayu manis mengandung beberapa jenis zat aktif seperti tannin, eugenol, safrole, kalsium oksalat, damar, saponin, zat penyamak, dan sinamaldehid (Sulistiyani etal. 2006). Menurut penelitian Wang et al. (2009) senyawa polifenol yang dominan pada daun kayu manis (C. burmannii) adalah dari golongan aldehid yaitu trans-sinnamaldehid sebesar 60,17\%. Komponen bioaktif dari golongan polifenol ini memiliki aktifitas seperti insulin (insulinmimetic) yang disebut zat methyl hydroxyl chalcone polymer (MHCP) (Jarvill-Taylor et al.2001).

Menurut Goldberg (2001) insulin juga berperan penting dalam proses metabolisme lipid pada jaringan adiposa dan hepar dan telah diuji oleh Jarvill-Taylor etal. (2001) secara in vitro; Qin et al. (2003) dan Preuss et al. (2006) pada kelinci; serta Chao et al. (2010) pada tikus. Karena memiliki aktivitas seperti insulin ini senyawa polifenol diduga dapat menurunkan kandungan lemak daging pada ikan. Pada kelinci kayu manis juga berpotensi sebagai antihiperkolesterolemia (Azima et al. 2004), dapat menurunkan total kolesterol sebesar 68,6\%, LDL kolesterol sebesar $66,6 \%$, dan kandungan trigliserida sebesar 49,9\%, serta peningkatkan HDL kolesterol sebesar 54,3\%.

Berdasarkan hal tersebut, maka diperlukan penelitian lebih lanjut untuk mengetahui efektivitas ekstrak serbuk daun tanaman kayu manis (Cinnamomumburmanii) terhadap Diferensiasi Leukositdan Aktivitas Fagositosis Ikan Nila (Oreochromis niloticus) yang Diinfesi Streptococcus agalactiae.

\section{STUDI LITERATUR}

\section{Ikan nila (Oreochromis niloticus)}

Ikan nila merupakan ikan yang berasal dari sungai Nil di Benua Afrika. Secara umum, ikan nila menpunyai bentuk tubuh panjang dan ramping dengan sisik berukuran besar, menonjol, dan bagian tepinya berwarna putih. Gurat sisi (linealiteralis) terputus dibagian tengan badankemudian berlanjut, tetapi letaknya lebi ke bawah dari pada letak garis yang memanjang di atas sirip dada. Jumlah sisik, dan sirip anal menpunyai jari-jari lemak tetapi keras dan tajam seperti duri. Sirip punggung dan sisip dadanya berwarna hitam. Bagian pinggir sirip punggung berwarna abu-abu atau hitam (Khairumandan Amri, 2008). Ikan nila meniliki kemanpuan menyasuaikan diriyang baik dengan lingkungan sekitarnya. Ikan nila juga memiliki toleransi yang tinggi terhadap lingkungan hidupnya, sehingga bisa dipeliara didaratan yang rendah yang berair payau maupun didaratan yang tinggi dengan suhu yang rendah. Ikan nila mampu hidup pada suhu $14-38^{\circ} \mathrm{C}$ dengan suhuterbaik adalah $25-30^{\circ} \mathrm{C}$. Hal yang paling berpengaruh dengan pertumbuhannya adalah salinitas atau kadar garam berkisar 0-29 \% sebagai kadar maksimal untuk tumbu dengan baik. Meskipun dapat hidup pada kadar garam sampai $35 \%$ manun jika ikan nila sudah tidak dapat tumbuh berkembang dengan baik (Ramdhan, 2010) 


\section{Daun Kayu Manis}

Cinnamomum sp. merupakantanaman rempah dari famili Lauraceae yang terdiri dari beberapa spesies (Rismunandar dan Paimin 2001). Di pasaran kayu manis dikenal dengan sebutan casiavera atau cinamon (Nazaruddin 1993) sedangkan dibeberapa daerah dikenal dengan nama huru mentek, ki amis (Sunda), manis jangan (Jawa), kenyengar (Madura), madang siaksiak (Toba), kulik manih (Minangkabau), onte (sasak), kuninggu (Sumba), puundinga (Flores), cingar (Bali), kacingar, dan kasingar (Nusa Tenggara) (Syukur dan Hernani 2002; Sutarto dan Atmowidjojo 2001). Kayu manis menyimpan khasiat yang luarbiasa. Hasil utama dari tanaman ini adalah kulit yang digunakan sebagai rempah. Kandungan kimianya antara lainminyak atsiri, safrole, sinamadehide, eugenol, tanin, damar, kalsiumoksanat, danzat penyamak. Sinamaldehida merupakan turunan dari senyawa fenol. Menurut Moestafa (1988) dan Chairul (1994) minyak atsiri dari $C$. burmanni memiliki komponen utama sinamaldehida dan dehidrokarveol asetat sedangkan menurut Gunawan dan Mulyani (2004) minyak atsiri C. burmanni mengandung sinamil aldehida, eugenol, linalool, kariofilena, dan asamsinamat. Senyawa lain yang ditemukan adalah flavonoid, tanin, triterpenoid dan saponin

\section{Streptococcus agalactiae}

Streptococcus adalah sel yang bulatatau sferis, tersusun berpasangan atau dalam bentuk rantai, merupakan bakteri Gram positif, mampu memproduksi kapsul polisakarida, dan mampu bertahan pada inang dalam temperatur tinggi (Lehmann dan Neumann, 1896). Streptococcus adalah golongan bakteri yang heterogen. Semua spesiesnya merupakan bakteri non motil, non sporing dan menunjukkan hasil negative untuk tes katalase, dengan syarat nutrisi kompleks. Semuanya anaerob fakultatif, kebanyakan berkembang di udara tetapi beberapa membutuhkan untuk berkembang. Semua spesies pada Streptococcus tidak dapat mereduksi nitrat. Streptococcus memfermentasi glukosa dengan produk utama adalah asam laktat, tidak pernah berubah gas. Banyak spesies merupakan anggota dari mikroflora normalpada membran mukosa pada manusia ataupun hewan, dan bersifat patogenik.

\section{Proses Aktivitas Fagositosis}

Fagositosis merupakan proses penelanan yang dilanjutkan dengan pencernaan seluler terhadap bahan-bahan asing yang masuk ke dalam tubuh dengan maksud mengganggu sistem homeostasis tubuh. Proses fagositosis secara garis besar dapat dibedakan dalam 3tahap:
a. Pengenalan dan pengikatan bahan asing.
b. Penelanan (ingestion)
c. Pencernaan

Fagositosissebagianbesardiperankan oleh makrofag sebab kemampuan fagositosisnya jauh lebih kuat dibandingkan dengan sel fagosit yang lain. Segera setelah menelan bahan asing tersebut, membran makrofag akan menutup. Partikel tersebut digerakkan ke dalam sitoplasma sel dan terbentuk vakuol fagosit. Lisosom adalah kantung-kantung dengan enzim, bersatu dengan fagosom membentuk fagolisosom. Pada keadaan ini dimulailahproses pencernaan intraseluler dan pembentukan zat bakterisidal jika lisosom gagal menerima bahan-bahan asing yang masuk ke dalam tubuh. Makrofag jaringan mempunyai kemampuan serupa makrofag aktif yang mampu mengembara ke seluruh jaringan, yaitu memfagosit bahan-bahan asing. 


\section{Diferensiasi Leukosit \\ Jenis Sel Darah Putih \\ Neutrofil}

Neutrofil (Polimorf), sel ini berdiameter $12-15 \mu \mathrm{m}$ memilliki inti yang khas padat terdiri atas sitoplasma pucat di antara 2 hingga 5 lobus dengan rangka tidak teratur dan mengandung banyak granula merah jambu (azuropilik) atau merah lembayung.

\section{Monosit}

Rupa monosit bermacam-macam, dimana ia biasanya lebih besar daripada leukosit darah tepi yaitu diameter 16-20 $\mu \mathrm{m}$ dan memiliki inti besar di tengah oval atau berlekuk dengan kromatin mengelompok. Sitoplasma yang melimpah berwarna biru pucat dan mengandung banyak vakuola halus sehingga memberi rupa seperti kaca. Granula sitoplasma juga sering ada. Prekursor monosit dalam sumsum tulang (monoblas dan promonosit) sukar dibedakan dari mieloblas dan monosit (Hoffbrand, dan Pettit 1996).

\section{Limfosit}

Sebagian besar limfosit yang terdapat dalam darah tepi merupakan sel kecil yang berdiameter kecil dari $10 \mu \mathrm{m}$. Intinya yang gelap berbentuk bundar atau agak berlekuk dengan kelompok kromatin kasar dan tidak berbatas tegas. Nukleolinormal terlihat. Sitoplasmanya berwarna biru-langit dan dalam kebanyakan sel, terlihat seperti bingkai halus sekitar inti. Kirakira 10\% limfosit yang beredar merupakan sel yang lebih besar dengan diameter 12-16 $\mu \mathrm{m}$ dengan sitoplasma yang banyak yang mengandung sedikit granula azuropilik. Bentuk yang lebih besar ini dipercaya telah dirangsang oleh antigen, misalnya virus atau protein asing (Hoffbrand, dan Pettit 1996).

\section{METODE PENELITIAN}

\section{Waktu dn Tempat Penelitian}

Penelitian telah dilakukan 1 Oktober 2017 di Laboratorium Budidaya Perikanan programstudi Budidaya Perikanan Fakultas Pertanian Universitas Muhammadiyah Gresik.

\section{Rancangan Penelitian}

Penelitian dilakukan menggunakan Rancangan Acak Lengkap (RAL) yang terdiri dari 3 perlakuan 4 ulangan serta control sehingga menghasilkan 20 unitpercobaan dan masing-masing unit percobaan diisi 10 ekor ikan. Model statistik RAL yang digunakan berdasarkan Steel \&Torrie (1993).

Dimana:

$$
Y_{i j}=\mu+\tau_{i}+\varepsilon_{i j} \text { atau } Y_{i j}=\mu_{i}
$$

\footnotetext{
$\mathrm{Y}_{\mathrm{ij}} \quad=$ Data respon yangdiamati pada perlakuanke-i dan ulangan ke-i

$\mu \quad=$ Nilai tengah

$\tau_{\mathrm{i}} \quad=$ Pengaruh perlakuan ke-i

$\varepsilon_{\mathrm{ij}} \quad=$ Galatpercobaan padaperlakuan ke-i dan ulangan ke-j
}

$\mathrm{K}+=$ Pemberian pakan komersial dengan ujitantang

$\mathrm{K}-=$ Pemberian pakan komersial tanpa uji tantang

$\mathrm{A}=$ Pemberian pakan dan penambahan dosis $0,25 \%$ serbuk daun tanaman kayu manis

$\mathrm{B}=$ Pemberian pakan dan penambahan dosis $0,5 \%$ serbuk daun tanaman kayu manis

$\mathrm{C}=$ Pemberian pakan dan penambahan dosis $1 \%$ serbuk daun tanaman kayu manis 


\section{Parameter Penelitian}

Parameter utama yang diamati merupakan Deferensial leukosit dan Aktifitas Fagositosis sedang parameter pendukung seperti Kualitas air (Suhu, DO, pH).

\section{Analisis Data}

Data yang diperoleh dari penelitian ini yangmeliputidiferensialleukosit Aktivitasfagositosis dan kualitas air dianalisa menggunakan program Minitab 16 lebih lanjut akan dilakukan uji lanjut Duncan dengan selang kepercayaan $95 \%$.

\section{HASIL DAN PEMBAHASAN}

Pengamatan diferensial leukosit selama 14 hari setelah infeksi S. agalactiaee (N14G). Data diferensial leukosit berupa hasil pengamatan limfosit, monosit dan neutrofil disajikan pada Gambar 1, 2, dan 3.

\section{Sel Limfosit}

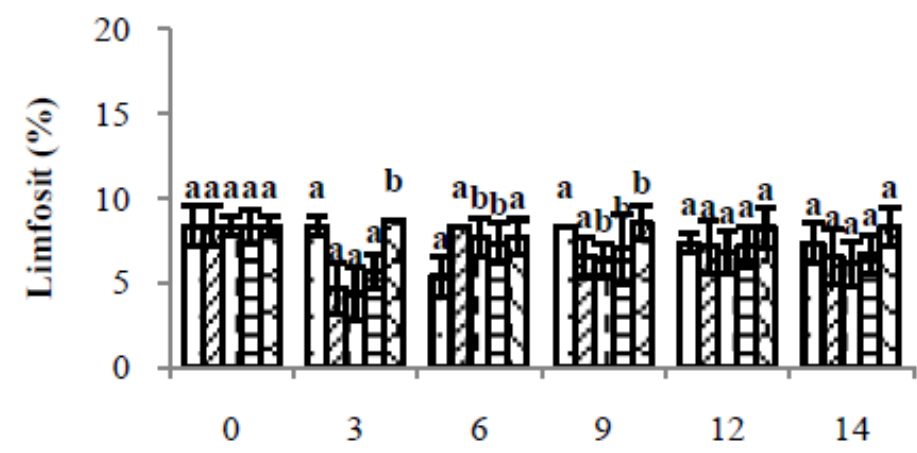

Gambar 1 .Hasil pengamatan limfosit ikannila dengan pemberian serbuk daun tanaman kayu manis dengan dosis berbeda.( $\square$ ) K- : kontrol negatif, ( $\square$ ) $\mathrm{K}+$ :kontrol positif, ( $\square$ )A: penambahan serbuk daun tanaman kayu manis0,25\%,( $\square) \mathrm{B}$ : penambahan sebuk daun tanaman kayu manis $0,5 \%$, $(\square) \mathrm{C}$ : penambahan serbuk daun tanaman kayu manis $1 \%$.

Berdasarkan hasil dari pengamatan diatas dijelaskan bahwa ikan telah di infeksi streptococcus agalatiae nilai limfositmengalami penurunan. Nilai limfosit tertinggi terjadi pasca uji tantang adalah perlakuan $\mathrm{C}$ sebesar $1,53 \%$ (lampiran 1) tidak berbeda nyata ( $>0.05)$ dengan control $(\mathrm{K}+)$ begitu juga pada hari ke 6 mengalami peningkatan pada perlakuan A sebesar 1.15\% dan B sebesar $2.08 \%$ tidak berbeda nyata dengan $(\mathrm{K}+)$ namun kondisi tersebut masih dalam kisaran jumlah limfosit ikan normal yaitu antara 71,12 - 82,88\% (Blaxhall dan Daisley).

Menurut Puspita 2014 menyimpulkan bahwa eksrtak kayu manis berpengaruh dalam menghambat pertumbuhan streptococcus agalatiae semakin besar konsentrasi ekstrak kayu manis (Cinnamaomum burmanii) maka semakin besar daya anti bakteri pada kayu manis. Penambahan serbuk daun tanaman kayu manis dalam pakan bertujuan meningkatkan jumlah limfosit. Hal ini di duga karena tannin kayu manis memiliki aktivitas anti bakreri yang berhubungan dengan kemampuanya untuk mengaktifkan adhesion sel mikroba juga mengaktifkan enzim mengganggu tranpor protein pada lapisan dalam sel (Cowan). Bijanti (2005) menjelaskan penurunan sel limfosit dipengaruhi adanya antigen asing sehinggazat kebal terganggu oleh masuknya infeksi yang menyebabkan jumlah limfosit menurun. Kono et al., 
(2002) sel limfosit yang teraktivasi oleh imunostimulan dapat meningkatkan aktivitas mitogenik yang diinduksi oleh concanavalin A ataulipopolisakarida dan menghasilkan macrophage activating factors. Tizard (1982) menyatakan penurunan limfosit disebabkan di darah perifer ditarik dari sirkulasi kedalam jaringan yang mengalami peradangan, adanya stres berkepanjangan akan meningkatkan kadar kortisol dalam darah sehingga menyebabkan hilangnya limfosit dalam sirkulasi darah dan organ limfoid.

\section{Sel Monosit}

Monosit terdiri dari sitoplasma berwarna biru keabu-abuan hingga biru, bentuk inti bervariasi mulai bulat hingga oval.

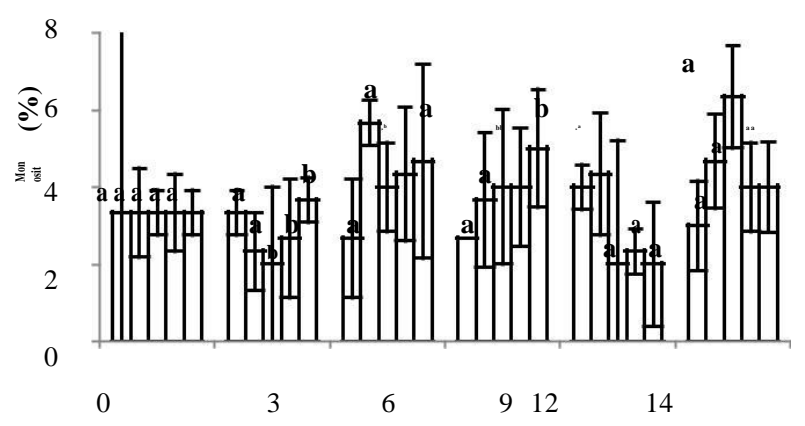

Gambar 2. Hasil pengamatan monosit ikan nila dengan pemberian serbuk daun tanaman kayu manis dengan dosis berbeda. ( $\square$ ) K-: kontrol negatif, ( $\square$ )K+: kontrol positif, ( $\square$ )A: penambahan serbuk daun tanaman kayumanis $0,25 \%$, ( $\sqsubset \mathbf{I}) \mathrm{B}$ : penambahan serbuk daun tanaman kayu manis $0,5 \%$, ( $匚$ I $) \mathrm{C}$ : penambahan serbuk daun tanaman kayu manis $1 \%$.

Berdasarkan hasil pengamatan monosit pada ikan nila setelah infeksi S. agalactiaee mengalami penurunan di hari ketiga. Penurunan terjadi pada perlakuan A sebesar $2.00 \%$ (lampiran 2) di hari ke 6 mengalami peningkatan secara dratis pada semua perlakuan. Perlakuan $\mathrm{K}+$ mengalami peningkatan sebesar $5.67 \%$ dan di hari ke 9 mengalami peningkatan pada perlakuan $\mathrm{C}$ sebesar $5.00 \%$ berbeda nyata dengan $(\mathrm{p}<0.05)$ dengan $\mathrm{K}+$. Peningkatanprosentase tersebut mengindikasikan peningkatan respon imun akibat serangan bakteri berupa peningkatan aktivitas fagositosis dimana diketahui bahwa sel monosit merupakan salah satu sel fagosit sebagai sistem pertahanan non spesifik. Menurut Rismunnandar (2001) minyak atsiri kayu manis dapat di manfaatkan sebagai antiseptik karena manpu menbunuh mikroorganisme.

Menurut Takashima dan Hibiya (1995) sel monosit ikan berbentuk bulat (oval), inti terletak di tengah sel dengan sitoplasmanya yang tidak berglanular. Lebih lanjut Fujaya (2004) menjelaskan bahwa sel monosit memiliki kemampuan yang lebihkuat dalam memfagosit antigen dibandingkan sel neutrofil. Amrullah (2004) menjelaskan bahwa cara kerja sel monosit dalam membunuh atau melisis sel bakteri dimana proses tersebut terdapat pada fase kemotaksis, fase penempelan, penangkapan, pemakanan dan pembunuhan bakteri. Mulyani (2006) menjelaskan bahwa sel monosit dapat menyediakan diri dengan cepat pada daerah inflamasi, memakan agen penyebab luka apabila terjadi serangan suatu penyakit.

Monosit merupakan salah satu sel fagosit peran penting dalam upaya menghancurkan patogen serta berperan pula sebagai antigen presenting cells (APC) yang berfungsi menyajikan 
antigen kepada sel limfosit (Kresno 2001; kollner et al, 2002). Lebih lanjut dijelaskan oleh Baratawidjaja (2006) bahwa monosit berasal dari sel progenitor umum dalam sumsum tulang. Setelah berpoliferasi dan matang, sel ini akan masuk ke dalam peredaran darah. Sel ini tidak hanya menyerang mikroba dan sel kanker namun juga berperan dalam memproduksi sitokin sebagai bentuk pertahanan dan dalam remodeling serta perbaikan jaringan bahkan sumber beberapa komplemen penting.

Peningkatan prosentase monosit selama proses infeksi disebabkan dalam tubuh ikan, mendorong monosit untuk menghancurkan benda asing yang masuk yaitu bakteri. Monosit merupakan sel dalam aliran darah dan berkembang menjadi makrofag. Ketika mengalami aktivasi, makrofag memiliki kapasitas fagosit lebih kuat daripada neutrofil meskipun granulosit mempunyai jumlah lebih besar (Irianto, 2005). Maftuch (2007) mengatakan bahwa pada proses inflamasi saat terjadi kerusakan jaringan oleh infeksi maupun reaksi antigen-antibodi, akan meningkatkan produksi monosit menjadi dua kali lebih banyak. Peredaran monosit dalam darah menjadi lebih singkat, pematangan monosit menjadi makrofag lebih cepat dan segera menuju ke jaringan yang rusak.

\section{Sel Neutrofil}

Neutrofil merupakan sel pagosit sistem polymorphonuklear yaitu sel yang bekerja cepat dalam melakukan fagosit tetapi tidak mampu bertahan lama. Sel ini berupa sel bundar dengan sitoplasmbergranula halus dan ditengahnya terdapat nukleus bersegmen (Tizard, 1982).

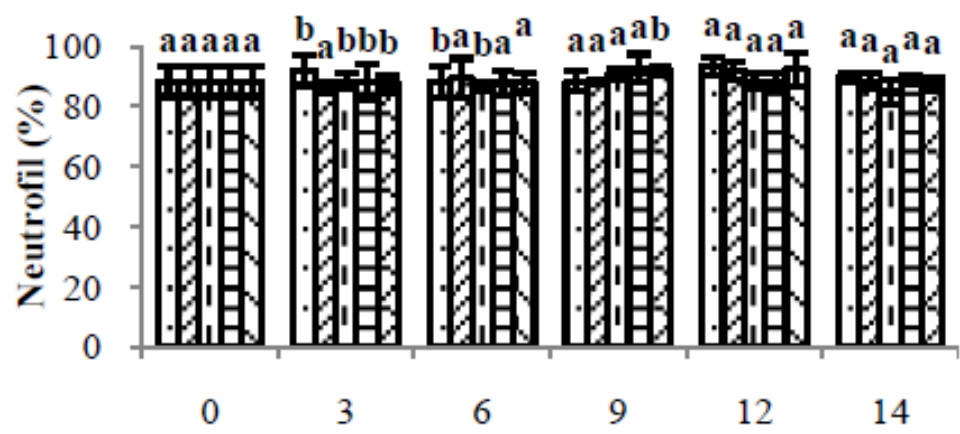

Gambar 3. Hasil pengamatan neutrofil ikan nila dengan pemberian serbuk daun tanamana kayu manis dengan dosis berbeda.( ) $\mathrm{K}$ - : kontrol negatif, ( )K+ :kontrol positif, ( )A: penambahan serbuk daun tanaman kayu manis 0,25\%, ( ) B: penambahan serbuk daun tanaman kayu manis $0,5 \%$, ( )C: penambahan serbuk daun tanaman kayu manis $1 \%$.

Hasil pengamatan neutrofil menunjukkan bahwa pada pengamatan pra (sebelum pemberian pakan perlakuan) dan pasca pemberian pakan daun kayu manis sebelum infeksi $S$. agalactiaee pada masing-masing perlakuan menunjukan nilai yang tidak berbeda nyata $(\mathrm{p}<0,05)$ dengan kontrol $(\mathrm{K}+)$. Sedangkan setelah infeksi S.agalactiaee menunjukkan penurunan hasilyang berbeda nyata $(\mathrm{p}<0,05)$ dengan kontrol $(\mathrm{K}+)$. Penurunan terjadi pada perlakuan $\mathrm{C}$ sebesar $87,67 \%$ tidak berbeda nyata denganperlakuan $\mathrm{K}+$. Hal tersebut mengindikasikan tidak adanya pengaruh pemberian pakan daun kayu manis pada ikan nila terhadap jumlah neutrofil ikan. Hasil berbeda nyata $(\mathrm{p}<0,05)$ dengan kontrol $(\mathrm{K}+)$ pada masing-masing perlakuan ditunjukkan pada pengamatan setelah uji tantang dengan infeksi bakteri $S$. agalactiae.

Streptococcus agalactiae masukdalam genus streptococcus golongan B. bakteri ini merupakan bakteri gram positif dimana kayu manis mempunyai aktivitas terhadap bakteri gram 
positif dan gram negatif. Beberapa peneliti terdahulu di sebutkan bahwa ekstrak kulit kayu manis lebih sensitif terhadap bakteri gram positifsalah satunya bakteri S. agalactiaee. Chinabut et al. (1991) menyatakan bahwa sel neutrofil berfungsi menghancuran bahan asing melalui proses fagositik yaitu kemotaksis dengan jalan sel bermigrasi menuju partikel atau perlekatan pertikel pada sel, penelanan partikel oleh sel dan penghancuran partikel oleh enzim lisosom didalam fagolisosom. Neutrofil dalam darah akan meningkat jika terjadi infeksi dan berperan sebagai pertahanan pertamadalam tubuh (Harikrishnan et al., 2010).

\section{Aktivitas Fagositosis}

Pengamatan aktivitas fagositosis selama 14 hari setelah infeksi S. agalactiaee (N14G). Pengaruh penambahan serbuk daun tanaman kayu manis pada pakan terhadap aktivitas fagositosis ikan nila setelah infeksi S. agalactiae disajikan pada Gambar 4.
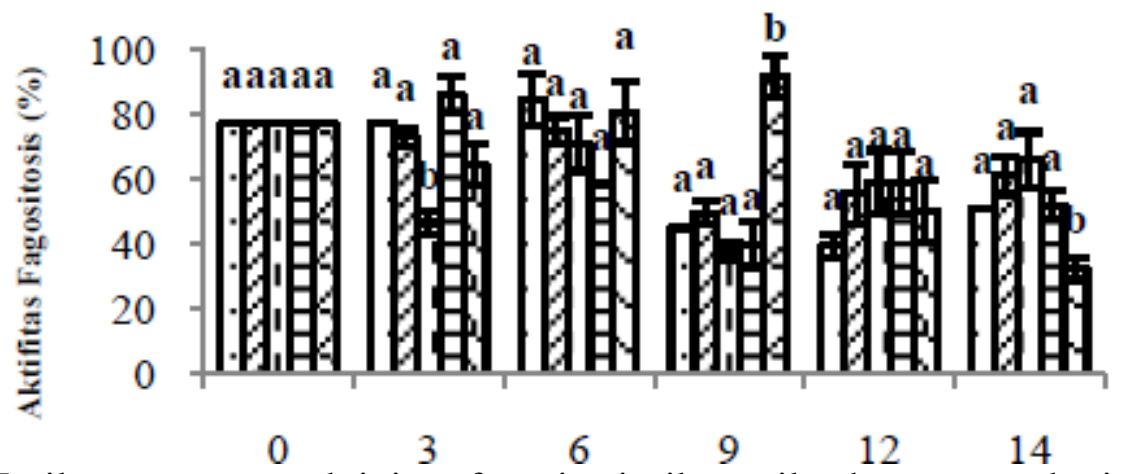

Gambar 4. Hasil pengamatan aktivitas fagositosis ikan nila dengan pemberian serbuk daun tanaman kayu manis dengan dosis berbeda. ( ) K- : kontrol negatif, ( )K+ :kontrol positif, ( )A: penambahan daun tanaman kayu manis 0,25\%, ( ) B: penambahan daun tanaman kayu manis $0,5 \%$, ( ) : penambahan daun tanaman kayu manis $1 \%$.

Hasil pengamatan menunjukkan bahwa aktivitas fagositosis terjadi setelah uji tantang (infeksi $S$. agalactiae) pada hari ke-3 dimana nilai tertinggi ditunjukkan oleh perlakuan B sebesar $86,00 \%$ tidak berbeda nyata $(\mathrm{p}<0,05)$ dengan perlakuan kontrol $(\mathrm{K}+)$. Peningkatan nilai aktivitas fagositosis diindikasikan karena selama uji tantang, proses fagositosis meningkat untuk melawan antigen (bakteri patogen) yang masuk ke dalam tubuh ikan, hal tersebut merupakan reaksi sistem imun non spesifik yang diperoleh dari pemberian pakan serbuk daun tanaman kayu manis. Hal ini berhubungan dengan senyawa-senyawa yang terkandung dalam ekstrak daun kayu manis yang dapat menghambat pertumbuhan bakteri Senyawa-senyawa tersebut memiliki sifat antibakteri dengan mekanisme yang berbeda-beda. Flavonoid dapat membentuk kompleks dengan protein ekstraseluler yang dapat merusak dinding sel bakteri yaitu terjadikebocoran sehingga mengakibatkan keluarnya senyawa intraseluler (Cowan 1999). Saponin mempunyai kerja merusak membran plasma dari bakteri (Hopkins 1999). Tanin memiliki aktivitas antibakteri yang berhubungan dengan kemampuannya untuk menginaktifkan adhesin sel mikroba juga menginaktifkan enzim dan menggangu transpor protein pada pada lapisan dalam sel (Cowan 1999). Selain hal tersebut, minyak atsiri daun kayu manis juga diketahui bersifat sebagai antibakteri.

Tizard (1998) menyatakan bahwa fagositosis merupakan pertahanan pertamadari respon selular yang dilakukan oleh selmonosit (makrofag) dan garnulosit (neutrofil). Proses fagositosis meliputi 4 tahapan yaitu kemotaksis (sel bermigrasi menuju partikel, tertarik oleh faktor 
kemotatik), pelekatan (sel melekat pada partikel yang diopsonisasi), penelanan sel (sel menelan partikel dan masuk di sitoplasma), dan pencernaan (partikel dicerna oleh enzim lisosim di dalam fagolisosom).

Menurut Alifuddin (2002) menyatakan bahwa ikan memiliki sistem kekebalan untuk mengantisipasi infeksi mikroorganisme dimana populasi sel B dan sel T sangat berperan dalam respon imun baik selular maupun humoral. Anderson (1974) dalam La sennung (2012) menyatakan bahwa respon selular merupakan respon yang bersifat non spesifik yang dilakukan oleh cell mediated immunity sedangkan respon imun humoral bersifat spesifik terkait dengan adanya produksi antibodi (immunoglobulin Ig). Baratawidjaja (2006), lebih lanjut menjelaskan bahwa respon imun non spesifik jumlahnya dapat meningkat karena infeksi oleh patogen yaitu meningkatnya jumlah leukosit selama fase akut pada infeksi penyakit. Seperti diketahui bahwa sistem ini merupakan pertahanan terdepan dalam menghadapi infeksi serangan oleh patogen.

\section{Kualitas Air}

Parameter yang di amati dalam penelitian ini adalah termasuk suhu, $\mathrm{Ph}$ dan $\mathrm{DO}$ yang akan di sajikan dalam table berikut:

Tabel 8. Data parameter kualitas air

\begin{tabular}{|c|c|c|c|c|c|}
\hline \multirow{3}{*}{$\begin{array}{r}\text { Perlakuan } \\
\text { K- (Kontrol) }\end{array}$} & \multicolumn{3}{|c|}{ Kisaran Kualitas air } & \multirow{2}{*}{\multicolumn{2}{|c|}{ DO (mg/l) }} \\
\hline & \multirow{2}{*}{\multicolumn{2}{|c|}{$\frac{\text { Suhu }\left({ }^{\mathbf{0}} \mathbf{C}\right)}{26,9-31,97}$}} & \multirow{2}{*}{$\frac{\mathbf{p H}}{8,45-8,51}$} & & \\
\hline & & & & 8,82 & $-8,92$ \\
\hline A (Dosis $0,25 \%)$ & 26,43 & $-29,1$ & $8,21-8,43$ & 8,69 & $-8,9$ \\
\hline B (Dosis 0,5\%) & 26,83 & $-29,73$ & $8,12-8,32$ & 8,52 & $-8,89$ \\
\hline $\begin{array}{l}\text { C (Dosis 1\%) } \\
\text { Kisaran }\end{array}$ & $\begin{array}{l}26,53 \\
25-32\end{array}$ & $-30,77$ & $\begin{array}{l}8,45-8,72 \\
6-9\end{array}$ & $\begin{array}{l}8,8- \\
3\end{array}$ & \\
\hline
\end{tabular}

Berdasarkan table di atas kisaran suhu pada seluruh akuarium perlakuan berkisaran antara $26,9^{\circ} \mathrm{C}-31,97^{\circ} \mathrm{C}$ yang merupakan kisaran suhu perairan terbaik untuk kehidupan Ikan. yang ideal untuk kehidupan ikan di daerah tropis sekitar $25-32^{\circ} \mathrm{C}$ (Mulyanto 1992). Menurut Sucipto (2008) peningkatan suhu juga menyebabkan terjadinya peningkatan dekomposisi bahan organik oleh bakteri, Suhu berpengaruh terhadap kehidupan, pertumbuhan ikan dan kecernaan pakan. Suhu air yang dibutuhkan dalam budidaya ikan nila yaitu $25-30^{\circ} \mathrm{C}$.

Parameter kualitas air pH pada seluruh akuarium perlakuan berkisaranantara 4,8-6,37. Kisran tersebut tergolong cukup rendah. Menurut Prakoso (2014), menyatakan bahwa sebagian besar organisme akuatik sensitif terhadap perubahan $\mathrm{pH}$, dan lebih menyukai $\mathrm{pH}$ netral yaitu antara 7-8,5. Namun pada penelitian ini ikan masih dapat hidup, tumbuh dan berkembang karena masih ada pada kisaran Ph 6. Menurut Effendi (2003) menyatakan bahwa pH air berpengaruh terhadap proses fisiologis di dalam tubuh organisme akuatik, termasuk ikan. Faktor yang mempengaruhi $\mathrm{pH}$ yaitu konsentrasi karbondioksida senyawa yang bersifat asam. Kisaran $\mathrm{pH}$ yang diperlukan oleh ikan nila yaitu 6-9 (Arie, 2007).

Nilai DO pada penelitian ini berkisar antara 8,8 - 9,4 mg/l. Nilai DO pada penelitian ini cukup tinggi untuk budidaya ikan nila. Sedangkan oksigen terlarut untuk budidaya ikan nila yaitu 3mg/1 (khairuman dan Amri, 2008). Lain halnya nilai DO untuk ikan nila 3 mg/l. Konsentrasi oksigen terlarut kurang dari $4 \mathrm{mg} / \mathrm{L}$ menimbulkan efek yang kurang menguntungkan bagi hampir semua organisme akuatik (Effendie 2003). Ikan nila termasuk jenis ikan yang tahan dalam kondisi kekurangan oksigen. jika terjadi kekurangan oksigen, ikan nila akan mengambil langsung oksigen dari udara bebas. Bahkan, ikan nila dapat bertahan hidup beberapa lama di 
darat tanpa air. Kandungan oksigen yang baik untuk ikan nila minimal $4 \mathrm{mg} /$ liter (Amri dan Khairuman 2013). Maka dari itu dengan DO yang tinggi ikan nila lebih tercukupi oksigen dan dapat berkembang dan tumbuh dengan baik.

\section{Kesimpulan}

1 Pemberian serbuk daun tanamankayu manis dalam pakan berpengaruh terhadap peningkatan diferensial leukosit terutama pada sel monosit dan sel neutrofil berbeda nyata $(\mathrm{P}>0,05)$ dibandingkan $\mathrm{K}+$ tanpa penambahan serbuk daun tanaman kayu manis sedangkan aktivitas fagositosis berpengaruh terhadap daya pathogen dari Streptococcus agacatiae.

2 Dosis $0,5 \%$ penambahan serbuk daun tanaman kayu manis pada pakan merupakan dosis yang terbaik.

\section{Saran}

Dosis $0,5 \%$ serbuk daun tanaman kayu manis dapat digunakan dalam upayapecegahan penyakit Streptococcus agalactiae. Perlu dilakukan penelitian lebih lanjut tentang penggunaan tanaman daun kayu manis guna pencegahan bakteri yang lainnya.

\section{UCAPAN TERIMA KASIH}

1. Ibu Ir. Endah Sri Redjeki, M.P, M.Phil selaku Dekan Fakultas Pertanian Universitas Muhammadyah Gresik.

2. Dr. Andi Rahmad R., S.Pi.,M.Si selaku ketua Program Studi Budidaya perikanan yang senantiasa memberikan motivasi kepada para mahasiswanya agar selalu semangat dalam mengerjakan tugas akhir ini.

3. Bapak Ir. Rahmad Jumadi, M.Kes selaku Dosen Pembibing 1 yang telah memberikan dukungan dan arahan untuk penyusunan skripsi.

4. Ibu Firma Fika Rahmawati, S.Pi, M.Si selaku Dosen Pembimbing 2 yang tidak pernah mengeluh atau bosan untuk memberikan motivasi serta bimbingan kepada para mahasiswanya agar mendapatkan hasil yang terbaik.

5. Bapak dan Ibu tercinta yang selalu berjuang, berdoa dan tidak pernah mengeluh untuk menberikan kasih sayang serta mencurahkan semua kekuatannyan demi menberikan yang terbaik bagi anak-anaknya.

6. Semua teman-temen super 15 yang telah banyak menbantu.

\section{DAFTARPUSTAKA}

Abas A, Lichtman AH, Dober JS. Cellular and Philadelphia: Elsevier Saunders; 2005

Alifudin, M. Priyono, A. Nurfatimah, A. 2002. Inventarisasi parasit pada Ikan Hias yang dilalulintaskan di bandara soekarno - hatta, cengkareng, jakarta. Jurnal Aquaculture Indonesia.1; 123-127.

Amrullah. 2004. Pengaruh imunostimulanSpirulina platensis untukmeningkatkan ketahanan tubuh ikan koi Cyprinus carpio terhadap virus herpes. [tesis]. Bogor (ID): InstitutPertanian Bogor.

Cholik, F., Jagatraya, A.G., Poernomo, R.P., danJauzi, A. 2005. Akuakultur Masyarakat Perikanan Nusantara (MPN) dan Taman Kuarium Air Tawar. Jakarta. 3 hal.

Rahmawati,F.F. 2015. Suplementasi mikrokapsul Probiotik melalui pakan sebagai pencegah infeksi Streptococcosis pada ikan nila (Oreochromis niloticus) Tesis.Institut Pertanian Bogor. Bogor. 